\title{
Improvement of the Statutory Framework for Construction and Demolition Waste Management exemplified in Germany and Australia
}

\author{
Mei Li, Anna Kühlen, Jay Yang and Frank Schultmann
}

\begin{abstract}
Construction and demolition (C\&D) waste occupies the largest share of overall waste generation in many countries. However, waste management practices and outcomes may differ between countries. For instance, in Australia, C\&D waste recovery is continuously improving during the last years but the amount of C\&D waste increases every year, as there has been little improvement in waste avoidance and minimization. In contrast, in Germany, waste generation remains constant over many years despite the continuous economic growth. The waste recycling rate in Germany is one of the highest in the world. However, most waste recycled is from demolition work rather than from waste generated during new construction. In addition, specific laws need to be developed to further reduce landfill of nonrecycled waste. Despite of the differences, C\&D waste generation and recovery in both countries depend on the effectiveness of the statutory framework, which regulates their waste management practices. This is an issue in other parts of the world as well. Therefore countries can learn from each other to improve their current statutory framework for C\&D waste management. By taking Germany and Australia as an example, possible measures to improve current practices of C\&D waste management through better statutory tools are identified in this paper. After providing an overview of the statutory framework of both countries and their status in waste generation and recovery, a SWOT analysis is conducted to identify strengths, weaknesses, opportunities and threats of the statutory tools. Recommendations to improve the current statutory frameworks, in order to achieve less waste generation and more waste recovery in the construction industry are provided for the German and Australian government and they can also be transferred to other countries.
\end{abstract}

\footnotetext{
M. Li $(\bowtie) \cdot J$. Yang

Queensland University of Technology, Brisbane, Australia

e-mail:m14.1i@student.qut.edu.au
}

\author{
A. Kühlen · F. Schultmann \\ Institute for Industrial Production (IIP)/French-German Institute for Environmental Research, \\ Karlsruhe Institute of Technology (KIT), Karlsruhe, Germany \\ e-mail: anna.kuehlen@kit.edu \\ J. Yang \\ e-mail: j.yang@qut.edu.au \\ F. Schultmann \\ e-mail: frank.schultmann@kit.edu
}

S. Rauch et al. (eds.), Urban Environment, DOI 10.1007/978-94-007-7756-9_2,

(C) Springer Science+Business Media Dordrecht 2013 


\section{Introduction}

Construction and demolition (C\&D) waste is a worldwide issue due to the rapid growth of towns and cities, and a significant number of illegal dumps [10]. It occupies the largest share of overall waste generation in many countries with their economic growth. The need and importance of C\&D waste management and minimization is being recognized around the world. However, the practices and outcomes related to this are different between countries. For example, in Australia, most of the C\&D waste (58\%) was recycled [5]. Despite the progress in waste recycling, there has been little improvement in waste avoidance, as the amount of waste continues growing every year $[4,5]$. Compared to Australia, the total volume of C\&D waste in Germany has remained constant over many years given the steadily growing economy [6]. The waste recovery rate in Germany is one of the highest in the world $[3,6]$ However, most waste recycled in Germany is from demolition work without much recovery from new construction waste. In addition, specific laws have yet to be developed to further reduce landfill of non-recycled waste.

The practices of waste management and minimization and situations of waste generation and recovery in Australia and Germany are regulated by their statutory framework of the government [13]. This is a common situation in other countries as well. There is the opportunity for different countries to learn from each other about experience and practice of the implementation of statutory tools for waste management.

The research presented in this paper intends to seek solutions to promote waste management and minimization practices through improved statutory framework. Take Germany and Australia as an example, it first provides an overview of the statutory frameworks in Germany and Australia and describes the status of waste generation and recovery in both countries. Then a SWOT analysis is performed to identify strengths, weaknesses, opportunities and threats of the statutory tools, before recommendations are proposed for both German and Australian governments to improve current statutory tools in order to result in more effective waste management and better outcomes of waste avoidance, minimization and recovery.

\section{Statistics and Statutory Framework for C\&D Waste Management in Germany}

\section{C\&D Waste Generation and Recovery in Germany}

C\&D waste in Germany mainly consists of excavated earth, construction and demolition debris, road construction waste, gypsum-based construction material and construction waste. Table 1 shows the composition of $C \& D$ waste and the status of recycling in 2004. It can be noted that most of the waste recycling took place in demolition waste and road scarification and only little in waste generated by new constructions and through excavation. 
Table 1 C\&D Waste Composition and Recycling in Germany, 2004 [12]

\begin{tabular}{|c|c|c|c|}
\hline \multirow[t]{2}{*}{ Waste type } & \multicolumn{2}{|c|}{ Total C\&D waste production } & \multirow{2}{*}{$\begin{array}{l}\text { Amount of waste recycled } \\
\text { Million tons }\end{array}$} \\
\hline & Million tons & $\%$ & \\
\hline Demolition waste & 50.5 & $25.2 \%$ & 31.1 \\
\hline Road scarification & 19.7 & $9.8 \%$ & 18.4 \\
\hline Construction waste & 1.9 & $0.9 \%$ & 0.1 \\
\hline Cement & 0.3 & $0.2 \%$ & - \\
\hline Total (without excavation) & 72.4 & $36.1 \%$ & 49.6 \\
\hline Waste from excavation & 128.3 & $63.9 \%$ & 9.1 \\
\hline Total & 200.7 & $100 \%$ & 58.7 \\
\hline
\end{tabular}

Table 2 C\&D Waste Balance 2008 in Germany [7]

\begin{tabular}{llclc}
\hline & & $\begin{array}{l}\text { C\&D waste } \\
\text { [million tons] }\end{array}$ & $\begin{array}{l}\text { Hazardous } \\
\text { waste } \\
\text { [million tons] }\end{array}$ & $\begin{array}{l}\text { Non-hazardous } \\
\text { waste } \\
\text { [million tons] }\end{array}$ \\
\hline Total & & 200.52 & 8.49 & 192.03 \\
Disposal & 24.02 & 3.71 & 20.31 \\
Of which & Landfill & 22.58 & 2.67 & 19.91 \\
& Incineration & 0.15 & 0.05 & 0.1 \\
& Treatment for disposal & 1.29 & 0.99 & 0.3 \\
Recovery & & 176.49 & 4.78 & 171.72 \\
Of which & Energy recovery & 0.82 & 0.2 & 0.62 \\
& Treatment for recovery & 175.67 & 4.58 & 171.09 \\
Recovery rate \% & & 88 & 56 & 89 \\
\hline
\end{tabular}

Regarding the general situation of C\&D waste treatment in Germany in 2008 as shown in Table 2, most of the recovered waste was dealt with by "treatment for recovery", which largely avoided high energy consumption in energy recovery. For disposal, most of the waste went to landfill, followed by the "treatment for disposal". Only a small part of the waste was incinerated.

\section{Statutory Tools}

In Germany, the statutory tools for waste management are reviewed and the key information of them is presented in Table 3.

\section{Statistics and Statutory Framework for C\&D Waste Management in Australia}

\section{C\&D Waste Generation and Recovery in Australia}

In Australia, the largest components of the C\&D waste stream and the most commonly recycled materials in Australia are concrete, bricks, asphalt, soil, timber and 
Table 3 Statutory Tools for C\&D Waste Management in Germany

\begin{tabular}{|c|c|c|}
\hline & Statutory tool & Key information \\
\hline \multirow[t]{4}{*}{$\begin{array}{l}\text { Legislation and } \\
\text { policies }\end{array}$} & $\begin{array}{l}\text { EU Waste Strategy and Waste } \\
\text { Framework Directive }\end{array}$ & $\begin{array}{l}\text { Waste prevention } \\
\text { Waste handling and hazardous waste } \\
\text { management }\end{array}$ \\
\hline & $\begin{array}{l}\text { Act for Promoting Closed } \\
\text { Substance Cycle Waste } \\
\text { Management and Ensuring } \\
\text { Environmentally Compatible } \\
\text { Waste Disposal }\end{array}$ & $\begin{array}{l}\text { Closed loop recycling } \\
\text { Responsibilities of waste producers }\end{array}$ \\
\hline & $\begin{array}{l}\text { The Law for the Prevention and } \\
\text { Disposal of Waste }\end{array}$ & $\begin{array}{l}\text { Transition from disposal to waste } \\
\text { management } \\
\text { Improvement of waste composition to } \\
\text { permit reuse and recycling }\end{array}$ \\
\hline & Commercial Wastes Ordinance & $\begin{array}{l}\text { Safe and high quality waste recovery } \\
\text { Residual waste container for waste } \\
\text { disposal }\end{array}$ \\
\hline \multirow[t]{3}{*}{$\begin{array}{l}\text { Strategy and } \\
\text { guidelines }\end{array}$} & $\begin{array}{l}\text { Strategy for the future of dis- } \\
\text { posal of waste from human } \\
\text { settlements }\end{array}$ & $\begin{array}{l}\text { Municipal waste recovery } \\
\text { Minimization of landfill }\end{array}$ \\
\hline & $\begin{array}{l}\text { The Certification of the German } \\
\text { Sustainable Building Council }\end{array}$ & $\begin{array}{l}\text { Sustainable building and construction } \\
\text { Waste minimization }\end{array}$ \\
\hline & $\begin{array}{l}\text { Guideline for Sustainable } \\
\text { Construction }\end{array}$ & $\begin{array}{l}\text { Sustainable construction throughout the } \\
\text { building life cycle } \\
\text { Minimization of the use of energy and } \\
\text { resources } \\
\text { Use of renewable and recoverable } \\
\text { materials }\end{array}$ \\
\hline \multirow[t]{3}{*}{$\begin{array}{l}\text { Technical } \\
\text { instructions }\end{array}$} & $\begin{array}{l}\text { Technical Instruction for Munici- } \\
\text { pal Waste }\end{array}$ & $\begin{array}{l}\text { Treatment and disposal of waste streams } \\
\text { Recycling of unavoidable waste } \\
\text { Reduction of toxic waste } \\
\text { Environmental-friendly waste treatment }\end{array}$ \\
\hline & DIN Standards & $\begin{array}{l}\text { Regulation of construction and deconstruc- } \\
\text { tion work } \\
\text { Construction work standards } \\
\text { General and contracting construction } \\
\text { issues } \\
\text { Handling of deconstruction materials }\end{array}$ \\
\hline & $\begin{array}{l}\text { European Waste Catalogue and } \\
\text { Hazardous Waste List }\end{array}$ & $\begin{array}{l}\text { A hierarchical list of waste descriptions } \\
\text { A consistent waste classification system }\end{array}$ \\
\hline $\begin{array}{l}\text { Voluntary } \\
\text { commitment }\end{array}$ & $\begin{array}{l}\text { Consortium of recycling manage- } \\
\text { ment in construction }\end{array}$ & $\begin{array}{l}\text { Until } 2011 \text { there had been a consortium } \\
\text { of construction industry stakehold- } \\
\text { ers to reduce landfilled construction } \\
\text { waste within } 10 \text { years by } 50 \% \text {. But } \\
\text { at the moment there is no voluntary } \\
\text { commitment of construction industry } \\
\text { stakeholders }\end{array}$ \\
\hline
\end{tabular}


Table 4 C\&D Waste Landfilled in NSW Australia, 2006-07 [8]

\begin{tabular}{lc}
\hline Waste Materials & Landfill by weight \\
\hline Paper and cardboard & $2 \%$ \\
Plastic & $2 \%$ \\
Ferrous metals & $3 \%$ \\
Garden organics & $4 \%$ \\
Timber & $13 \%$ \\
Soil and rubble & $25 \%$ \\
Concrete, asphalt, brick and sand & $31 \%$ \\
Other & $20 \%$ \\
Total & $100 \%$ \\
\hline
\end{tabular}

Table 5. Recycling Rates for $\mathrm{C} \& \mathrm{D}$ Waste by Jurisdiction, 2006-07 [5]

\begin{tabular}{ll}
\hline Jurisdiction & Recycling Rate \\
\hline NSW & $67 \%$ \\
VIC & $72 \%$ \\
QLD & $30 \%$ \\
WA & $17 \%$ \\
SA & $79 \%$ \\
ACT & $91 \%$ \\
TAS & Unknown \\
NT & Unknown \\
\hline
\end{tabular}

ferrous metals, because they are usually demolished in large quantities and have an existing market for reuse and recycling (e.g. concrete, bricks and asphalt), or they have a relatively high commercial value (e.g. metals) [5]. There is no consolidated data available at the national level about the specific compositions of C\&D waste, which is land filled or recovered in Australia, because there are different waste categories used in each jurisdiction. Take New South Wales for example, the largest C\&D waste components by weight land filled from 2006 to 2007 were concrete, asphalt, bricks and sand (31\%), soil and rubble (25\%), and timber (13\%), as shown in Table 4.

Although the recovery of C\&D waste in Australia has improved significantly in recent years, it varies in different jurisdictions because of the different waste management laws and enforcement. Data in some jurisdictions is even unavailable. The waste recycling rates from 2006 to 2007 achieved by each jurisdiction are shown in Table 5.

\section{Statutory Tools}

Information related to the Australian statutory tools for C\&D waste management is summarized in Table 6. 
Table 6 Statutory Tools for C\&D Waste Management in Australia

\begin{tabular}{|c|c|c|}
\hline & Statutory tool & Key information \\
\hline \multirow[t]{3}{*}{$\begin{array}{l}\text { Legislation and } \\
\text { policies }\end{array}$} & $\begin{array}{l}\text { National Waste Policy: } \\
\text { Less Waste, More } \\
\text { Resources }\end{array}$ & $\begin{array}{l}\text { Resource recovery and waste management } \\
\text { Reduction of waste disposal }\end{array}$ \\
\hline & $\begin{array}{l}\text { National Environment } \\
\text { Protection Measures }\end{array}$ & $\begin{array}{l}\text { National objectives to protect the environment } \\
\text { Several mandatory national regulations }\end{array}$ \\
\hline & $\begin{array}{l}\text { The Product Stewardship } \\
\text { Bill } 2011 \text { (Product } \\
\text { Stewardship Act 2011) }\end{array}$ & $\begin{array}{l}\text { A national framework to manage the environmental, } \\
\text { health and safety impacts of products } \\
\text { Regulated and voluntary activities }\end{array}$ \\
\hline \multirow[t]{2}{*}{$\begin{array}{l}\text { Strategy and } \\
\text { guidelines }\end{array}$} & $\begin{array}{l}\text { National Strategy for } \\
\text { Ecologically Sustain- } \\
\text { able Development }\end{array}$ & $\begin{array}{l}\text { An integrated approach for waste prevention and } \\
\text { minimization } \\
\text { Improvement of resource usage and reduction of the } \\
\text { impact of waste disposal } \\
\text { Avoidance and handling of hazardous waste }\end{array}$ \\
\hline & $\begin{array}{l}\text { Carbon Pollution Reduc- } \\
\text { tion Scheme (CPRS) }\end{array}$ & $\begin{array}{l}\text { Main driver to reduce greenhouse gas emissions } \\
\text { Reduction of greenhouse gas emissions through } \\
\text { reduction of waste landfill and increased waste } \\
\text { recycling }\end{array}$ \\
\hline $\begin{array}{l}\text { Technical } \\
\text { instructions }\end{array}$ & $\begin{array}{l}\text { Green Star Certified } \\
\text { Ratings }\end{array}$ & $\begin{array}{l}\text { Reduction of the environmental impact of buildings } \\
\text { Achievement of waste recycling, occupant health } \\
\text { and productivity, and cost savings } \\
\text { Innovation in sustainable building practices }\end{array}$ \\
\hline \multirow[t]{2}{*}{$\begin{array}{l}\text { Voluntary } \\
\text { commitment }\end{array}$} & $\begin{array}{l}\text { Australian Packaging } \\
\text { Covenant }\end{array}$ & $\begin{array}{l}\text { Reduction of the environmental impacts of con- } \\
\text { sumer packaging } \\
\text { Avoidance, minimization, reuse and recycling of } \\
\text { packaging waste }\end{array}$ \\
\hline & $\begin{array}{l}\text { Sustainable Packaging } \\
\text { Guidelines }\end{array}$ & $\begin{array}{l}\text { Optimization of consumer packaging for effi- } \\
\text { cient resource usage and environmental impact } \\
\text { reduction } \\
\text { Design, manufacture and end-of-life management } \\
\text { of sustainable packaging }\end{array}$ \\
\hline
\end{tabular}

\section{SWOT Analysis}

SWOT analysis is applied in this research to compare the statutory tools of waste management in Germany and Australia. SWOT is an acronym for strengths, weaknesses, opportunities and threats [11]. SWOT analysis was popularized by [1] It is used to develop four types of strategies, namely SO (strengths-opportunities) strategies, WO (weaknesses-opportunities) strategies, ST (strengths-threats) strategies, and WT (weaknesses-threats) strategies [2, 9].

Through SWOT analysis, the strengths, weaknesses, opportunities and threats of the statutory tools of both Germany and Australia are identified, as shown in Table 7. Strategies indicated by SO, WO, ST, WT are also established and explained in the table. 
Table 7 SWOT Analysis of the Statutory Framework for C\&D Waste Management in Germany

\begin{tabular}{|c|c|c|c|}
\hline \multicolumn{4}{|l|}{ Germany } \\
\hline & & Strengths (S) & Weaknesses (W) \\
\hline & & $\begin{array}{l}\text { Waste prevention and } \\
\text { minimization is top of the } \\
\text { preference. } \\
\text { Most statutory tools include } \\
\text { C\&D waste section or } \\
\text { target on C\&D waste. } \\
\text { Sustainable construction } \\
\text { in the national scope to } \\
\text { strengthen understand- } \\
\text { ing and standardise } \\
\text { actions in achieving waste } \\
\text { minimization. } \\
\text { Standard waste classification } \\
\text { according to EU waste } \\
\text { catalogue. } \\
\text { Technical instructions for } \\
\text { real practice of waste } \\
\text { management }\end{array}$ & $\begin{array}{l}\text { Lack of specific regulatory sup- } \\
\text { port for waste minimization } \\
\text { from suppliers' packaging on } \\
\text { construction site. } \\
\text { No voluntary commitments }\end{array}$ \\
\hline $\begin{array}{l}\text { Opportu- } \\
\text { nities } \\
\text { (O) }\end{array}$ & $\begin{array}{l}\text { Increase recycling } \\
\text { of (new) con- } \\
\text { struction waste } \\
\text { and excavation } \\
\text { waste }\end{array}$ & $\begin{array}{l}\text { SO } \\
\text { Specific regulations and } \\
\text { support on increasing con- } \\
\text { struction waste recycling } \\
\text { on new construction sites } \\
\text { and of excavation waste }\end{array}$ & $\begin{array}{l}\text { WO } \\
\text { Regulations on minimising } \\
\text { packaging. } \\
\text { Commitment of the stakeholders } \\
\text { of the construction industry } \\
\text { with set, high quality targets } \\
\text { for waste recycling and reuse }\end{array}$ \\
\hline $\begin{array}{l}\text { Threats } \\
\text { (T) }\end{array}$ & $\begin{array}{l}\text { Most of the } \\
\text { disposed waste } \\
\text { goes to landfill }\end{array}$ & $\begin{array}{l}S T \\
\text { Policies to reduce landfill } \\
\text { New technologies of waste } \\
\quad \text { disposal to minimise the } \\
\text { impact on the environment }\end{array}$ & $\begin{array}{l}W T \\
\text { Encourage packaging reuse } \\
\text { and new technologies on } \\
\text { packaging } \\
\text { New technologies of waste } \\
\text { degradation } \\
\text { Commitment of the stakeholders } \\
\text { to prevent landfill and increase } \\
\text { recycling of excavation waste }\end{array}$ \\
\hline
\end{tabular}

\section{Recommendations}

Based on the findings from the SWOT analysis, recommendations are provided for both countries to improve their government regulations to encourage better waste management practices in the construction industry.

\section{Recommendations for Germany}

Recommendations drawn from the SWOT analysis for the improvement of German statutory tools for C\&D waste management are listed in Table 9. 
Table 8 SWOT Analysis of the Statutory Framework for C\&D Waste Management in Australia

\begin{tabular}{|c|c|c|c|}
\hline \multicolumn{4}{|c|}{ Australia } \\
\hline & & $\mathrm{S}$ & $\mathrm{W}$ \\
\hline & & $\begin{array}{l}\text { Waste prevention and minimiza- } \\
\text { tion is top of the preference. } \\
\text { Focus on collaborations of } \\
\text { stakeholders in achieving } \\
\text { waste management targets. } \\
\text { Waste minimization and } \\
\text { management is nested in } \\
\text { broader concepts of resource } \\
\text { efficiency, carbon pollution } \\
\text { reduction and ecological } \\
\text { sustainable development. } \\
\text { Specific regulations and } \\
\text { guidelines for products and } \\
\text { materials packaging from } \\
\text { manufacturing industry to } \\
\text { assist waste minimization on } \\
\text { construction site }\end{array}$ & $\begin{array}{l}\text { Most statutory tools address gen- } \\
\text { eral waste management rather } \\
\text { than C\&D waste specifically. } \\
\text { No standard classification of waste } \\
\text { categories at national level. } \\
\text { Lack of technical instructions for } \\
\text { C\&D waste management in real } \\
\text { practice }\end{array}$ \\
\hline $\mathrm{O}$ & $\begin{array}{l}\text { Establish market } \\
\text { of recycled } \\
\text { materials }\end{array}$ & $\begin{array}{l}\text { SO } \\
\text { Guidelines for the establishment } \\
\text { of recycled materials market } \\
\text { Financial support from the } \\
\text { government to encourage the } \\
\text { use of recycled materials and } \\
\text { components }\end{array}$ & $\begin{array}{l}\text { WO } \\
\text { Technical instructions for } \\
\text { construction waste handling, } \\
\text { management, transportation, } \\
\text { reuse, recycling and sale } \\
\text { Develop standards for different } \\
\text { recycled materials }\end{array}$ \\
\hline $\mathrm{T}$ & $\begin{array}{l}\text { No consolidated } \\
\text { data at the } \\
\text { national level } \\
\text { Different develop- } \\
\text { ment of construc- } \\
\text { tion industry and } \\
\text { waste recycling } \\
\text { in different } \\
\text { jurisdictions } \\
\end{array}$ & $\begin{array}{l}S T \\
\text { Collaboration of different juris- } \\
\text { dictions in waste minimiza- } \\
\text { tion and recycling } \\
\text { Develop national waste database } \\
\text { to encourage comparison } \\
\text { with other countries for } \\
\text { improvement }\end{array}$ & $\begin{array}{l}W T \\
\text { Develop standard and uniform } \\
\text { waste classification system at } \\
\text { national level } \\
\text { Establish and improve the current } \\
\text { statutory tools to address prob- } \\
\text { lems related to C\&D waste }\end{array}$ \\
\hline
\end{tabular}

\section{Recommendations for Australia}

Recommendations drawn from the SWOT analysis for the improvement of Australian statutory tools for C\&D waste management are listed in Table 10.

\section{Conclusions}

C\&D waste minimization is an important contributor to the goal of achieving sustainability of the construction industry. In order to regulate $C \& D$ waste management practices, governments around the world have established statutory tools to 
Table 9 Recommendations for the improvement of statutory tools for C\&D waste management in Germany

\begin{tabular}{|c|c|c|}
\hline Statutory tool & Specific issue & Issue description \\
\hline \multirow[t]{2}{*}{$\begin{array}{l}\text { Financial } \\
\text { support for }\end{array}$} & $\begin{array}{l}\text { Newly-construction } \\
\text { waste recycling }\end{array}$ & $\begin{array}{l}\text { The government needs to provide financial } \\
\text { support to the client and waste management } \\
\text { companies to increase waste recovery from } \\
\text { newly construction processes }\end{array}$ \\
\hline & $\begin{array}{l}\text { The development of } \\
\text { innovations on waste } \\
\text { reduction }\end{array}$ & $\begin{array}{l}\text { The government needs to provide financial } \\
\text { support to the construction industry, con- } \\
\text { struction material manufactures and research } \\
\text { associations for technological innovations on } \\
\text { waste reduction, for instance innovation in } \\
\text { material packaging and waste recovery, and } \\
\text { alternative options for waste disposal }\end{array}$ \\
\hline \multirow[t]{2}{*}{ Legislations for } & $\begin{array}{l}\text { Reducing waste landfill } \\
\text { and reduction of } \\
\text { down-cycling }\end{array}$ & $\begin{array}{l}\text { The German government needs to establish } \\
\text { relevant legislations for the reduction of } \\
\text { waste landfill and material down-cycling, for } \\
\text { instance by checking construction waste on } \\
\text { site and respective payments }\end{array}$ \\
\hline & $\begin{array}{l}\text { Waste minimization by } \\
\text { manufacturers }\end{array}$ & $\begin{array}{l}\text { It is necessary for the German government } \\
\text { to establish material design standard and } \\
\text { product stewardship, and develop regulations } \\
\text { and policies for manufacturers to recover } \\
\text { packaging }\end{array}$ \\
\hline $\begin{array}{l}\text { Voluntary commit- } \\
\text { ment for }\end{array}$ & $\begin{array}{l}\text { The high quality } \\
\text { construction waste } \\
\text { recycling and reuse } \\
\text { and prevention of } \\
\text { landfill }\end{array}$ & $\begin{array}{l}\text { In the past the consortium "Kreislaufwirtschaft- } \\
\text { sträger Bau (KWTB)" of construction } \\
\text { industry stakeholders existed, which made } \\
\text { a voluntary commitment with the govern- } \\
\text { ment to reduce landfilled construction waste } \\
\text { (excluding excavation waste) within } 10 \text { years } \\
\text { by } 50 \% \text {. A similar voluntary commitment of } \\
\text { the industry stakeholders including excava- } \\
\text { tion waste and preventing landfill should be } \\
\text { established again }\end{array}$ \\
\hline
\end{tabular}

reduce waste generation and encourage waste recovery. The effectiveness of these statutory frameworks has resulted in different waste management status in different countries. Therefore countries can learn from each other about good experience in developing waste management regulations and practices in waste minimization and recovery.

This paper discusses the comparison of different statutory frameworks for C\&D waste management by taking Germany and Australia as an example. It firstly outlines the current statutory tools for C\&D waste management in both countries and presents their situations of C\&D waste generation and recovery. A SWOT analysis is conducted to identify their strengths, weaknesses, opportunities and threats with relevant strategies for improvement. Finally the recommendations are provided for Germany and Australia to improve their statutory frameworks and promote their industry practices of waste minimization and recovery. The recommendations for Germany include financial support for newly-construction waste recycling, legislations 
Table 10 Recommendations for the improvement of statutory tools for C\&D waste management in Australia

\begin{tabular}{|c|c|c|}
\hline Statutory tool & Specific issue & Issue description \\
\hline $\begin{array}{l}\text { Financial support } \\
\text { for }\end{array}$ & Waste recovery & $\begin{array}{l}\text { Government needs to set up financial incentive } \\
\text { programs to encourage waste recovery, and to } \\
\text { maintain and develop the recycled material market } \\
\text { to drive more waste recovery in the industry }\end{array}$ \\
\hline Legislations for & $\begin{array}{l}\text { C\&D waste specific } \\
\text { issues }\end{array}$ & $\begin{array}{l}\text { Legislations for C\&D waste need to be established } \\
\text { for waste minimization throughout the project life } \\
\text { cycle by the coordination and collaboration among } \\
\text { all the project stakeholders }\end{array}$ \\
\hline $\begin{array}{l}\text { Technical instruc- } \\
\text { tions for }\end{array}$ & $\begin{array}{l}\text { Overall C\&D waste } \\
\text { management }\end{array}$ & $\begin{array}{l}\text { Technical instructions and guidance on C\&D waste } \\
\text { handling and hazardous waste management } \\
\text { need to be established and reviewed and revised } \\
\text { regularly }\end{array}$ \\
\hline \multirow[t]{2}{*}{$\begin{array}{l}\text { National system } \\
\text { for }\end{array}$} & Waste classification & $\begin{array}{l}\text { Standard and uniform waste classification system } \\
\text { needs to be developed at the national level, in } \\
\text { order to facilitate data exchange, comparison and } \\
\text { benchmarking }\end{array}$ \\
\hline & Waste data tracking & $\begin{array}{l}\text { A national waste data tracking system should also be } \\
\text { established to collect and store a comprehensive } \\
\text { range of data on waste generation, disposal to } \\
\text { landfill and resource recovery }\end{array}$ \\
\hline $\begin{array}{l}\text { National guide- } \\
\text { lines for }\end{array}$ & $\begin{array}{l}\text { Sustainable } \\
\text { construction }\end{array}$ & $\begin{array}{l}\text { National guidelines to promote nationally waste } \\
\text { minimization and recovery throughout the whole } \\
\text { building life cycle }\end{array}$ \\
\hline
\end{tabular}

for reducing waste landfill, legislations for waste minimization by manufacturers, and incentive measures for technological innovation of packaging minimization and recovery. For Australia, recommendations are provided including waste legislations specific to C\&D waste, technical instructions for C\&D waste management, national waste classification system, national waste data tracking system, guidelines for sustainable construction, and financial incentives for waste recovery.

The result of this research will provide a valuable reference for both German and Australian government to improve their current statutory frameworks for C\&D waste management. It is also applicable to other countries to review and update their regulatory tools for $\mathrm{C} \& \mathrm{D}$ waste management.

\section{References}

1. Andrews KR (1965) The concept of corporate strategy. Dow Jones-Irwin, Homewood

2. Babaesmailli M, Arbabshirani B, Golmah V (2012) Integrating analytical network process and fuzzy logic to prioritize the strategies-A case study for tile manufacturing firm. Expert Systems with Applications

3. European Commission (2010) Being wise with waste: the EU's approach to waste management

4. EPHC (2009) National Waste Overview In: E. P. A. H. Council (ed) 


\section{焦 Springer}

http://www.springer.com/978-94-007-7755-2

Urban Environment

Proceedings of the 11th Urban Environment Symposium

(UES), held in Karlsruhe, Germany, 16-19 September 2012

Rauch, S.; Morrison, G.; Norra, S.; Schleicher, N. (Eds.)

2013, XXI, 526 p. 164 illus., 90 illus. in color., Hardcover

ISBN: $978-94-007-7755-2$ 